\title{
РОБОТА ВЧИТЕЛЯ НАД ЗАСВОЄННЯМ ФРАЗЕОЛОГІЗМІВ, ЩО ІЛЮСТРУЮТЬ НЕВЕРБАЛЬНУ ПОВЕДІНКУ УКРАЇНЦІВ
}

Демиденко Г. Г. Робота вчителя над засвоєнням фразеологізмів, що ілюструють невербальну поведінку українців.

У статті подано систему роботи над розумінням і засвоєнням фразеологізмів тематичної групи «невербальне спілкування» у старшій школі; акцентовано увагу на екстралінгвістичному принципі навчання фразеології, що відображає виховний i розвивальний характер сталих висловів; 3'ясовано їх лінгвокультурологічний потенціал, пов'язаний із народним світоглядом, поведінкою українців як носіїв національного характеру. Подано практичні завдання 3 коментарями, розроблені автором і покликані виробити вміння розумітися на процесах семантизації стійких зворотів з невербальним компонентом, підвищити результативність роботи з культури спілкування. 
Ключові слова: невербальне спілкування, невербальна поведінка, фразеологізм, лінгвокультурологія, національний характер, культура спілкування, принципи навчання фразеології.

Демиденко А.Г. Робота учителя над усвоением фразеологизмов, иллюстрирующих невербальное поведение украинцев.

В статье представлена система роботы над пониманием и усвоением фразеологизмов тематической группы «невербальное общение» в старшей школе; акцентируется внимание на экстралингвистическом принципе обучения фразеологии, который отображает воспитательный и развивающий характер устойчивых выражений; раскрывается их лингвокультурологический потенциал, взаимосвязанный с народным мировоззрением, поведением украинцев как носителей национального характера. Поданы практические задания с комментариями, разработанные автором, которые помогут выработать умение ориентироваться в процессах семантизации фразем с невербальным компонентом, повысить результативность роботы по культуре общения.

Ключевые слова: невербальное общение, невербальное поведение, фразеологизм, лингвокультурология, национальный характер, культура общения, принципы обучения фразеологии.

Demydenko H.H. Teaching approaches in mastering skills of using phraseology units illustrating Ukrainian non-verbal behavior.

The article represents a system of teaching approaches and means used for improving senior pupils' comprehension and skills in using phraseology units defying nonverbal communication. This research is also focused on emphasizing the nonlinguistic principle of vocabulary learning which uncovers the educational potential of idioms. The paper reveals linguistic and cultural nature associated with Ukrainian people's outlook and behavior. Moreover it gives a set of practical tasks commented by the authors and designed to develop the ability to comprehend the semantization processes of idioms with nonverbal component and to increase the efficiency of communicative culture.

Key words: non-verbal communication, non-verbal behavior, idiom, linguistics, national character, communicative culture, phraseology learning principles.

Вивчення рідної мови, оволодіння ії фразеологічним багатством $\epsilon$ необхідною передумовою пізнання світу, формування духовної етнонаціональної культури молоді. Крім того, системне, цілеспрямоване вивчення фразеології $\epsilon$ важливою умовою формування мовної особистості, 3 одного боку, і становлення iii духовних цінностей - 3 іншого [8, с. 3].

Однією із проблем сучасної лінгводидактики є пошуки шляхів $\mathrm{i}$ засобів підвищення ефективності вивчення фразеології у школі (Л. Кожуховська, І. Мисан, Л. Соловець, О. Тесленко, Т. Форостюк та ін.). Вирішенню ii значною мірою сприяють зміна парадигми

С Г. Г. Демиденко, 2015. 
мовознавчих досліджень і зміни в освітньому процесі. Так, скажімо, для гуманітарних дисциплін важливими питаннями $є$ спрямування наукового вітчизняного потенціалу в русло національних цінностей, етнопсихології та етнопедагогіки, культури, мистецтва, що сприятиме вихованню майбутнього свідомого покоління, громадян, носіїв мови.

Практичне значення вивчення фразеології полягає передовсім у підвищенні культури мовлення школярів. Крім того, 3'являється можливість виховної роботи, оскільки значення більшості сталих висловів увиразнює ментальність народу, висвітлює народне сприймання вітчизняної історії, ставлення народу до різноманітних суспільних і побутових проблем, позитивних і негативних рис людської вдачі. Зміст сучасних програм (5-11, 5-12 класи) з української мови передбачає вивчення фразеології так би мовити у два етапи: безпосередньо в середній школі, коли з'ясовуються специфічність фразеологізмів, визначаються їх мовні особливості й у старшій школі, де увага зосереджується на узагальненні та систематизації знань, однак не завжди цей процес постає якісно новим для учнів. Обмежена кількість годин стримує учителя на шляху до поглиблення фразеологічних знань учнів i тим самим вони позбавляються можливості пізнати мовні закономірності, які не спромоглися усвідомити через особливості віку та психічного розвитку.

Новітні фразеологічні студії «чекають» впровадження у шкільну практику. Незважаючи на свою науковість й інколи затеоретизованість вони є окремими частинами глобального процесу оновлення української лінгвістики, переосмислення таких цінностей як національне багатство, ментальність народу, культурне надбання, духовне життя тощо. Ці поняття так чи так стосуються мови, випливають із законів іiі розвитку чи відображають у собі іiі унікальність і самобутність. У зв'язку з цим закономірною постає потреба в розширенні горизонтів вивчення певних шкільних розділів мови, особливо фразеології, послуговуючись надбаннями інших дисциплін: психології, культурології, етнології та ін.

Цікавим для 3'ясування вказаних вище питань може бути вивчення паралінгвальних фразеологізмів, що вирізняються своїми особливостями 3-поміж інших тематичних груп фразеологічних одиниць, як-от: фраземи 3 компонентом кольоративом, зоофразеологізми, соматичні, темпоральні фразеологізми, сталі 
вислови на позначення рис характеру людини, її емоційної сфери, стійкі сполучення з етнокультурним змістом тощо.

Сучасні науковці справедливо зазначають, що українська фраземіка загалом є своєрідним джерелом, у якому віддзеркалюється всіма своїми гранями історія, суспільні взаємини минулих епох, заняття людей, їхня виробнича діяльність, побут, мораль, родинні стосунки, звичаї, вірування й повір'я. У цьому матеріалі також відображено природне середовище, у якому жив i живе український народ, своєрідність рослинного і тваринного світу, а також сама людина, тобто iї вигляд, міміка, жести, психічний і фізіологічний стан [4, с. 187].

Зазначимо, що фразеологізми на позначення невербального спілкування носіїв мови (жести, міміка, особливості погляду, постави, ходи, особливості вимови, інтонації), тобто омовлення так званої «мови тіла», кваліфікуємо як паралінгвальні фразеологічні одиниці (ПФО).

На думку Л. Соловець, робота 3 фразеологізмами тематичної групи «вербальне i невербальне спілкування» дає змогу розширити фразеологічний запас учнів, довести важливість правил гречної поведінки людей у суспільстві, ознайомити 3 нормами етикету у спілкуванні, 3 особливостями українського національного етикету, сприяє реалізації комунікативної та діяльнісної змістових ліній навчання української мови [7, с. 5]. Дисертаційна праця методиста присвячена роботі над фразеологізмами як засобом формування культури спілкування молодших школярів, а тому відповідно досить актуальним $є$ питання про особливості засвоєння вказаних фразем учнями старшої школи.

Мета нашої статті - представити авторський підхід до аналізу паралінгвальних фразеологізмів української мови у старшій школі, прокоментувати особливості внутрішньої форми тих чи тих висловів, акцентувати на їх етнокультурному тлі; розкрити значний навчальновиховний потенціал паралінгвальних зворотів у формуванні культури мовлення, комунікативної компетенції загалом через виконання розроблених вправ.

Закономірно, робота 3 фразеологізмами на позначення несловесних засобів спілкування сприяє усвідомленню учнями того, що невербаліка несе не менш правдиву й важливу інформацію, ніж вербальні засоби. За таких умов уміння витлумачити той чи той паралінгвальний вияв $\epsilon$ запорукою кращого розуміння тактики 
спілкування у групі людей. У наукових розвідках О. Шумиліної йдеться про те, що у методиці розвитку мовлення дітей при виборі методів і прийомів роботи над фразеологізмами важливо врахувати таке: суб'єкт навчання машинально і окремішно спирається на компоненти фразеологізму й окремо сприймає як значення його слів, а не як смислову цілісність, що набула у фразеологічному виразі нового, метафоричного значення [11]. У результаті власного дослідження специфіки паралінгвальних сталих зворотів можемо зробити висновок, що цим висловам притаманні, крім універсальних ознак, характерних для більшості фразем, також національно-мовні ознаки, які знаходять відображення у специфічних значеннях, у лексично-компонентному складі, у структурних моделях i особливостях їх уживання. Водночас паралінгвальні номінації мають $i$ суттєві відмінності від звичайних стійких висловів. Їхня специфіка полягає в тому, що в них спостерігається інше співвідношення між буквальним значенням компонентів та їхнім цілісним значенням. При вербалізації жесту стійкими словосполученнями спостерігаються дві площини значення: позначення кінеми як власне фізичної дії i значення, властиве кінемі як знаку. Тому основною особливістю невербальних номінацій уважають двоплановість семантичної структури, у якій наявність значеннєвих компонентів, що передають об'єктивні знання, полегшує зберігання образного змісту фразеологізмів [1, с. 134-135].

На сучасному етапі розвитку методики навчання української мови одним з ефективних прийомів роботи з фразеологізмами є словникова робота. Особливу увагу варто звернути на характер словників, які мають бути запропоновані учням на уроці, адже крім фразеологічних словників доцільно користуватися словниками жестів і міміки. Учні можуть укласти власні словники, використовуючи здобутки лексикографічної практики, власний довід, довідники з невербального спілкування. Зіставлення сталого вислову та слова-ідентифікатора або ж загалом паралінгвальної одиниці покращить ефективність семантизації знайомих і незнайомих стійких зворотів, дасть змогу розкрити особливості його вживання.

Специфіку співвідношення жестових одиниць (у широкому значенні) і фразем, внутрішня форма яких зафіксувала окремий вияв «мови тіла», відображено в Таблиці 1. 
Таблиияя 1

\section{Співвідношення жестів та ПФО}

\begin{tabular}{|c|c|c|c|}
\hline Жест & Тлумачення жесту & Фразеологізм & $\begin{array}{c}\text { Тлумачення } \\
\text { фразеологізму } \\
\end{array}$ \\
\hline $\begin{array}{l}\text { Бити себе в } \\
\text { груди }\end{array}$ & $\begin{array}{l}\text { Має релігійне значення і } \\
\text { виражає ідею покаяння; } \\
\text { спрямованість руху руки на } \\
\text { груди пов'язана } 3 \text { тим, що саме } \\
\text { на них знаходиться натільний } \\
\text { хрест - традиційний сакральний } \\
\text { предмет для клятви }\end{array}$ & $\begin{array}{l}\text { бити себе } \\
\text { [кулаком] } \quad \text { в } \\
\text { груди }\end{array}$ & $\begin{array}{lr}\text { гаряче запевняти, } \\
\text { переконувати } \\
\text { небудь у чомусь }\end{array}$ \\
\hline $\begin{array}{l}\text { Вип'ячувати } \\
\text { губу }\end{array}$ & $\begin{array}{l}\text { Жестикулянт виставляє } \\
\text { (вип'ячує) уперед нижню губу, } \\
\text { що вказує на несвідомий вираз } \\
\text { дитячого обличчя, характерного } \\
\text { для моменту п्ञлачу, } \\
\text { незадоволення }\end{array}$ & $\begin{array}{l}\text { копилити } \\
\text { губу }\end{array}$ & $\begin{array}{l}\text { 1) пишатися, } \\
\text { зазнаватися; } \\
\text { 2) ображатися, } \\
\text { сердитися }\end{array}$ \\
\hline $\begin{array}{l}\text { Схилити } \\
\text { голову }\end{array}$ & $\begin{array}{l}\text { Жестикулянт стоячи схиляє } \\
\text { голову й дивиться вниз; поза } \\
\text { виражає скорботу та покору }\end{array}$ & $\begin{array}{l}\text { хилити } \\
\text { (клонити) } \\
\text { голову }\end{array}$ & $\begin{array}{l}\text { виявляти покору перед } \\
\text { ким-небудь, } \\
\text { підкорятися комусь; } \\
\text { виявляти шану, повагу } \\
\text { до кого-, чого-небудь; } \\
\text { журитися, } \\
\text { засмучуватися, бути у } \\
\text { відчаї }\end{array}$ \\
\hline $\begin{array}{l}\text { Тикати / } \\
\text { вказувати } \\
\text { пальцем }\end{array}$ & $\begin{array}{l}\text { Вказівний } \quad \text { жест. } \\
\text { напрямок, указує на предмет, } \\
\text { про який говорять; } \epsilon \\
\text { неввічливим }\end{array}$ & $\begin{array}{l}\text { тикати } \\
\text { (цтрикати, } \\
\text { показувати) } \\
\text { пальцями } \\
\text { (пальцем) }\end{array}$ & $\begin{array}{l}\text { негативно } \\
\text { висловлюватися про } \\
\text { кого-небудь, відкрито; } \\
\text { засуджувати когось }\end{array}$ \\
\hline $\begin{array}{l}\text { Показувати } \\
\text { дулю }\end{array}$ & 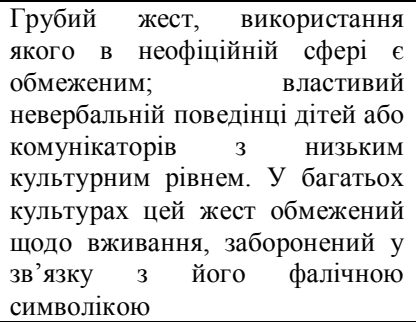 & $\begin{array}{l}\text { показувати } \\
\text { дулю (фігу) }\end{array}$ & $\begin{array}{l}\text { відмовити кому-небудь } \\
\text { у чомусь, нічого не } \\
\text { дати, не допомогти і } \\
\text { т. ін. }\end{array}$ \\
\hline $\begin{array}{l}\text { Показувати на } \\
\text { двері }\end{array}$ & 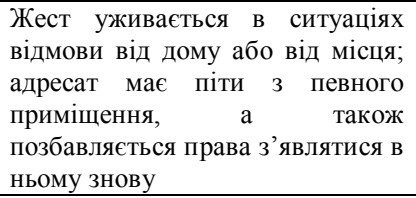 & $\begin{array}{l}\text { показувати } \\
\text { на двері }\end{array}$ & $\begin{array}{l}\text { виганяти, проганяти } \\
\text { когось звідки-небудь }\end{array}$ \\
\hline $\begin{array}{l}\text { Обіймати / } \\
\text { обхвачувати / } \\
\text { обхватити [за } \\
\text { шию (за плечі, }\end{array}$ & $\begin{array}{l}\text { Вираження теплого, лагідного } \\
\text { ставлення до іншої людини } \\
\text { (найчастіше це привітання при } \\
\text { зустрічі, прощанні). } \text { Знак }\end{array}$ & $\begin{array}{l}\text { вішатися } \\
\text { (кидатися, } \\
\text { чіплятися) } \\
\text { на иию }\end{array}$ & $\begin{array}{l}\text { нав'язуватися кому- } \\
\text { небудь, настирливо } \\
\text { домагаючись } \\
\text { прихильності, }\end{array}$ \\
\hline
\end{tabular}

(ㄷ Г. Г. Демиденко, 2015. 


\begin{tabular}{|l|l|l|l|}
\hline за талію)] & $\begin{array}{l}\text { вдячності; прохання пробачити; } \\
\text { розрада. Характерний для } \\
\text { родинних, інтимних і дружніх } \\
\text { стосунків. }\end{array}$ & $\begin{array}{l}\text { взаємності (про жінок у } \\
\text { ставленні до чоловіків). }\end{array}$ \\
\hline
\end{tabular}

Дослідження концептуалізації невербальної поведінки визначає, що специфіка фразеологізмів, прототипами яких є одиниці невербальної мови, визначається значною мірою світобаченням народу, особливостями його культури й побуту. Національно-культурні елементи семантики паралінгвальних фразем виявляються переважно у прямому значенні сукупного словесного комплексу, оскільки невербальні засоби спілкування $\epsilon$ культурними реаліями i фрагментами національноспецифічної моделі світу. Фразеологічні засоби вираження невербальних засобів спілкування можуть бути інтерпретовані як продукти вияву специфіки мови та культури відповідної мовної спільноти.

Аналіз мовних засобів представлення невербальних знаків уможливив установлення специфічних рис української невербальної традиції, що дає змогу відтворити етноспецифічну невербальну семіотичну систему за іï мовним описом. Саме у старшій школі доречними і зрозумілим для учнів є міжмовні паралелі, які формують розуміння специфіки української мови, фразеології, iї самобутності на тлі інших, близькоспоріднених мов.

Наведемо особливості міжмовного зіставлення сталих зворотів у групі східнослов'янских мов у Таблиці 2.

Таблицяя 2

Міжмовне зіставлення ПФО

\begin{tabular}{|c|c|c|}
\hline \multicolumn{3}{|c|}{ ФРАЗЕОЛОГІЗМ } \\
\hline украӥнський & російський & білоруський \\
\hline \multicolumn{2}{|c|}{$\begin{array}{c}\text { уживаються задля вираження негативних почуттів (злості, } \\
\text { гніву, незадоволення тощо) }\end{array}$} & \\
\hline $\begin{array}{l}\text { очі метають іскри; } \\
\text { [ажс] іскри з очей сиплються } \\
\text { (летять, скачуть); } \\
\text { кресати очима; } \\
\text { метати очима (3 очей) } \\
\text { іскри }\end{array}$ & метать искры (молнии) & \\
\hline $\begin{array}{l}\text { спадати з лиця (на лиці, на } \\
\text { виду) - } \\
\text { «1) ставати блідим, } \\
\text { змученим; марніти; } \\
\text { 2) у стані, близькому до } \\
\text { занепаду» }\end{array}$ & $\begin{array}{lrll}\text { сnасть } & \text { с } \\
\text { «осунуться» } & \end{array}$ & \\
\hline $\begin{array}{lc}\text { чухати } & \text { потилицю (2олову, } \\
\text { чуба, } & \text { чуприну) }\end{array}$ & $\begin{array}{l}\text { чесать затылок- } \\
\text { «1) быть } \quad \text { озадаченным }\end{array}$ & $\begin{array}{l}\text { naчухаць } \quad \text { nambылiцy } \\
\text { «паклапаціцца, падумаць, як }\end{array}$ \\
\hline
\end{tabular}




\begin{tabular}{|c|c|c|}
\hline 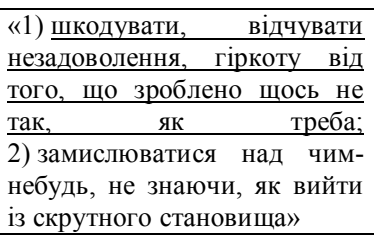 & $\begin{array}{l}\text { чем-либо; } \\
\text { 2) зевать, ротозейничать, } \\
\text { обычно во время работы» }\end{array}$ & $\begin{array}{l}\text { выйсці з пэўнай сітуацыі»; } \\
\text { чухаць namblлiцy (-bl) - «быць } \\
\text { заклапочаным, засмучаным». }\end{array}$ \\
\hline \multicolumn{3}{|c|}{ уживаються задля вираження почуття жаху } \\
\hline $\begin{array}{l}\text { волос (волосся) } \\
\text { (дубом, дуба) стає; } \\
\text { волос в'яне; } \\
\text { волосся стори стало; } \\
\text { волосся дротом [стає] }\end{array}$ & $\begin{array}{lr}\text { волосы } & \text { становятся } \\
\text { (стают, поднимаются) } \\
\text { дыбом }\end{array}$ & \\
\hline $\begin{array}{l}\text { махнути рукою - «1) перестати } \\
\text { займатися ким, чим-небудь, } \\
\text { турбуватися про когось, щось, } \\
\text { збайдужіти до когось, чогось; } \\
\text { 2) не турбувати, не чіпати } \\
\text { когось; 3) перестати сподіватися } \\
\text { на щось, чекати чогось» }\end{array}$ & & $\begin{array}{l}\text { махнуць рукой - «перестаць } \\
\text { звяртаць увагу на кого, што-н., } \\
\text { перестать цікавіцца кім, чым- } \\
\text { н» }\end{array}$ \\
\hline $\begin{array}{ll}\text { надувати (надимати) губки } \\
\text { - «1) гніваючись, } \\
\text { ображаючись тощо, надавати } \\
\text { обличчю } & \text { незадоволеного } \\
\text { вигляду; } & \text { 2) виражати } \\
\text { зверхність, } & \text { поважність; } \\
\text { пишатися, зазнаватися». }\end{array}$ & $\begin{array}{l}\text { надувать губы (дубки) - } \\
\text { «сердиться, обижаться, } \\
\text { делая недовольное лицо, } \\
\text { выражать неудовольствие, } \\
\text { досаду и т. п.» }\end{array}$ & \\
\hline $\begin{array}{l}\text { zнути (дерти, задирати i } \\
\text { т. ін.) кирпу }(\text { носа, нic) }- \\
\text { «гордовито триматися, бути } \\
\text { чванливим, } \\
\text { зазнаватися» }\end{array}$ & 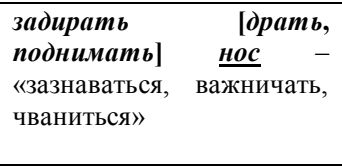 & \\
\hline 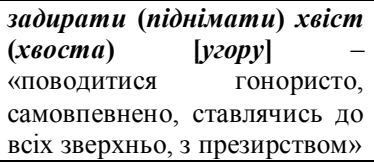 & $\begin{array}{l}\text { задирать хвосm - «не } \\
\text { считаться ни с кем и ни с } \\
\text { чем, не обращать } \\
\text { внимания ни на кого и ни } \\
\text { на что» } \\
\end{array}$ & \\
\hline \multicolumn{3}{|c|}{ загальне значення «кокекувати» } \\
\hline $\begin{array}{l}\text { посилати бісики; } \\
\text { пускати бісики } \text { [очима } \\
(\text { оком)]; пускати гудзики } \\
{[\text { очима (оком)]; пускати }} \\
\text { гедзики }\end{array}$ & строить [делать] глазки & \\
\hline $\begin{array}{lr}\text { роззявляти } & \text { (розкривати) } \\
\text { рот - } & \\
\text { «1) починати } & \text { говорити, } \\
\text { висловлювати якесь бажання; } \\
2) \text { виявляти } \\
\text { зацікавлення, захоплення чи } \\
\text { здивування, слухаючи когось } \\
\end{array}$ & & $\begin{array}{l}\text { паразяўляць (паразявіць) } \\
\text { раты - «1) крайне здзівіцца, } \\
\text { стаць моцна уражаным (пра } \\
\text { ўсіх, многіх); 2) зазяваўшыся, } \\
\text { перастаць рабіць што-н. (пра } \\
\text { ўсіх, многіх)» }\end{array}$ \\
\hline
\end{tabular}

() Г. Г. Демиденко, 2015. 


\begin{tabular}{|c|c|c|}
\hline $\begin{array}{l}\text { або розглядаючи щось; } \\
\text { 3) посягати, зазіхати на що- } \\
\text { небудь чуже; } \\
\text { 4) просити їсти, голодувати; } \\
\text { 5) бути неуважним, } \\
\text { неквапливим» }\end{array}$ & & \\
\hline $\begin{array}{l}\text { очі розбіzаються - «хтось не } \\
\text { може зосередити увагу на } \\
\text { чомусь одному, дивиться то } \\
\text { на одне, то на інше» }\end{array}$ & 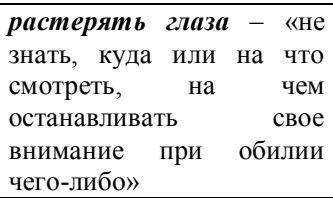 & \\
\hline $\begin{array}{l}\text { сковзати очима (поглядом) } \\
-\quad \text { «мимохідь дивитися на } \\
\text { кого-, що-небудь» }\end{array}$ & $\begin{array}{l}\text { краем глаза - «мельком, } \\
\text { очень краткое время } \\
\text { (видеть что-либо)» }\end{array}$ & \\
\hline $\begin{array}{l}\text { на високих } \begin{array}{c}\text { нотаx } \\
\text { «підвищеним } \\
\text { голосом }\end{array} \text { від } \\
\text { обурення, } \\
\text { радості і т. ін.» }\end{array}$ & & $\begin{array}{l}\text { на высокіх нотах (на высокай } \\
\text { ноце) }- \text { гаварыць, } \\
\text { пагаварываць - «вельмі гучна, } \\
\text { нядобразычліва» }\end{array}$ \\
\hline $\begin{array}{l}\text { zнутися (згинатися) в дуzу } \\
\text { (в три погибелі) - } \\
\text { «плазувати, запобігати перед } \\
\text { кимсь, } \\
\text { покірність» } \\
\end{array}$ & & 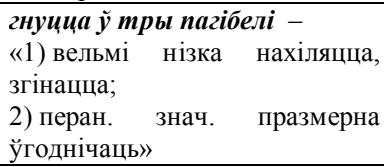 \\
\hline $\begin{array}{l}\text { витягтися (витягнутися) } \boldsymbol{y} \\
\text { нитку - «докласти всіх } \\
\text { зусиль, щоб зробити щось } \\
\text { незвичайне, } \\
\text { неможливе» }\end{array}$ & $\begin{array}{l}\text { вытягиваться в струнку } \\
\text { (струну) - «становиться } \\
\text { на вытяжку» }\end{array}$ & \\
\hline \multicolumn{3}{|c|}{$\begin{array}{l}\text { уживається для } \quad \text { вираження заперечення, незгоди», } \\
\text { використовується в зневажливому значенні «абсолютно, } \\
\text { зовсім нічого }\end{array}$} \\
\hline дуля з маком [nід ніс]-» & $\begin{array}{l}\text { фига [шиш, кукиш] с } \\
\text { маслом }\end{array}$ & \\
\hline $\begin{array}{l}\text { показувати } \frac{\text { дулю }}{\text { «відмовити кому-небудь }}- \\
\text { «ом } \\
\text { чомусь, нічого не дати, не } \\
\text { допомогти іт. ін.» }\end{array}$ & 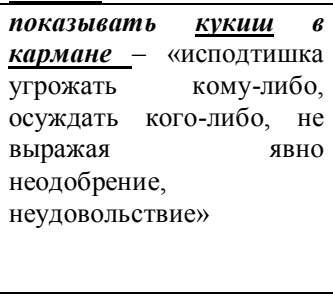 & 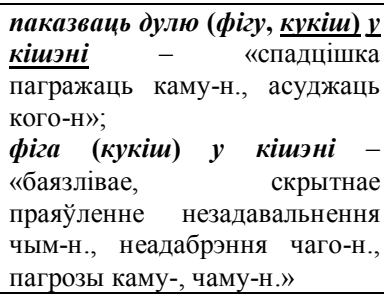 \\
\hline
\end{tabular}

\section{Паралінгвальні фразеологізми також можуть утворювати} синонімічні ряди, подекуди мають антонімічну пару. Синонімічні відношення таких стійких висловів визначаються через особливість невербального компонента в їхньому складі. Це насамперед якісна характеристика емоцій, почуттів, емоційних станів, які можуть виражатися за допомогою різних невербальних засобів. Наприклад: 
емоція страху може бути репрезентована такими висловами: [аж] волосся піднімається (підіймається, встає, лізе) вгору (догори); волос (волосся) дибом (дубом, дуба) стає; вбирати (втягувати) голову в плечі; $[$ аж $(i)]$ очі на лоб (на лоба рідше догори) лізуть; брови полізли на лоба; лиця нема; спадати з лиця.

Антонімічних пар паралінгвальних фразем зафіксовано незначну кількість, а саме: відкрито глянути у вічі - «не соромитися перед кимнебудь за свої вчинки», й опустити очі [в землю, додолу] -«відчувати незручність, сором, збентеження, дивитися вниз; засоромитися, знітитися». Так, вислів давати волю ногам означає «1) тікати, швидко бігти, уникати якоїсь небезпеки; 2) завзято, запально танцювати», антонімом для першого значення ПФО є зворот ледве (ледь, насилу) тягти (тягнути, тягати, волочити) ноги - «дуже повільно ходити, рухатися (через утому, хворобу, старість)». Для такого психофізіологічного процесу як почервоніння обличчя внаслідок сильного переживання, хвилювання, сорому, збудження характерними $\epsilon$ стійкі вислови: зайнятися (залитися) рум'янщем; кидає в краску; [аж] кров кинулася до обличчя (в обличчя, в лище), антонімом для цих висловів є фразеологізм спадати / спасти з лиия, який означає «ставати блідим, змученим, худнути; марніти». За тим же принципом протиставляються ПФО колоти очима - обнімати поглядом (оком, очима), які виражають протилежні ставлення до об'єкта спостереження чи пізнання. Фразеологізм квасити губи означає «виявляти незадоволення, засмучуватися, плакати від чого-небудь», антонімом до нього є вислів, який також «залучає» до своєї структури слово «губи», однак у цьому разі вони виражають позитивний настрій суб'єкта: [аж] губи облизувати, тобто «бути дуже задоволеним чим-небудь».

Наведемо кілька вправ, спрямованих на вивчення паралінгвальної фразеології у школі.

Вправа 1. Знайти в реченнях паралінгвальні фразеологізми та пояснити їх значення за словником (у запропонованих реченнях мовні одиниці виокремлено).

1. Народе! Я кладу земний уклін твоєму полю і твоєму дому! (М. Рильський). 2. Очі вилазили йому з голови, кров у пульсах товклася так сильно, що бачилось, ось-ось потріскають жили (I. Франко). 3. Скорше... Скорше... Щоб тільки перебратися щасливо на другий берег, а там... Попалять пороми й судна та покажуть Меншикову дулю С Г. Г. Демиденко, 2015. 
(Б. Лепкий). 4. Сафрон темними, без блиску очима впинається в Тимофію і говорить якомога спокійніше та голосно (М. Стельмах). 5. Очі, знаєте, наскрізь тебе пропікають. Стою, як потороча, ні пари 3 уст (І. Муратов). 6. Дзвоню зубами, бо мені зимно (М. Коцюбинський). 7. Становий здивованим поглядом змірив Семена від голови до п'ят, наче не сподівався такої упертості (М. Коцюбинський). 8. Врешті Лазар 3'явився. Його обступили, питали, кололи очима (М. Коцюбинський). 9. Дорошенко вбирає поглядом простір лиману (О. Гончар). 10. - А будьте за це могорич? А вже я вам цю справу так вироблю, що аж губи оближите (І. Нечуй-Левицький). 11. Яків ще раз обвів хату. Очі його упали на бабу Оришку (Панас Мирний). 12. - Найми, - каже Ох, - у мене: я його [сина] вивчу. Тільки $з$ такою умовою: як вибуде рік та прийдеш за ним, то як пізнаєш, - ще рік служитиме у мене! - Добре, каже чоловік. Ударили по руках (Нар. казка).

Вправа 2. Дібрати синоніми до фразеологізмів (у дужках наводимо синонімічний ряд).

1) лупати очима - у значенні «соромно» (очі вилазять; опустити очі [в землю, додолу]; кліпати (блимати) очима; вбирати (втягувати) голову в плечі);

2) зуби скриплять - у значенні «гніватися, сердитися» (показати [своі] зуби (роги, пазурі); скреготати (скреготіти, скриготіти, скрипіти) зубами; очі блиснули [гнівом]; світити очима (оком, білками); [аж] очі рогом; очі метають іскри; очі запалали (саме у негативному значенні); витріщити (вивалити, вирячити, вилупити) очі (баньки);

3) брови полізли на лоба - у значенні «здивуватися» (робити великі очі; [аж (i)] очі на лоб (на лоба, рідше догори) лізуть; лупати очима; витріщити (вивалити, вирячити, вилупити) очі (баньки); роззявити рота; [аж] ударити об поли руками; битися (бити [себе]) об поли [руками]);

4) дерти носа (голову) [вгору] - у значенні «зазнаватися, чванитися» (кривити рот (губи, уста); дерти носа (голову) [вгору]; гнути (дерти, задирати) кирпу (носа, ніс); дути губу (морду); скривити (склеїти, зробити) кислу міну; квасити губи; розквасити губи; надувати (надимати) губи; братися фертом в (попід) боки; копилити губу (губи, носа, ніс); крутити носом);

5) очі загорілися - у значенні «сильне емоційне збудження; 
симпатія, любов» (обіймати (обнімати) поглядом (оком, очима); їсти (поїдати, жерти, пожирати) очима (оком); очі [так i] світяться очі грають; бісики грають (стрибають, рідше іскряться) в очах; очі загорілися; блиснути очима (оком).

Вправа 3. Подайте розгорнуте тлумачення фразеологізмів: крутити носом; ламати (заламувати, ломити) руки; бити по руках; переминатися (переступати) з ноги на ногу; приставити шапку; знімати шапку (бриль, капелюх). Відповідно одразу наведемо коментарі до запропонованих лінгвоодиниць.

Крутити носом первинно означало «відвернути ніс від людини, або іншого об'єкта, що мав специфічний, стійкий, можливо, навіть неприємний запах і з огляду на це триматися від нього на відстані». 3 часом значення фразеологізму стало більш узагальненим і сам запах не мався на увазі як основний показник в оцінці ситуації спілкування. Однак не варто зменшувати значення органу нюху під час комунікації: учені неодноразово заявляли, що ніс допомагає людині визначитися у своєму ставленні до інших, виявляти прихильність, недовіру, неприязнь, любов.

Вислів на зразок ламати (заламувати, ломити) руки - «жестом, виглядом виражати переживання, страждання, хвилювання; побиватися, плакати» що, на думку психологів, є специфічно жіночим жестом. До «жіночих знаків» належать такі: заламувати руки від відчаю, закривати долонями очі від страху; стояти, упертися руками у стегна, показуючи своє обурення або рішучість настояти на своєму, сидячи в задумливості, підперти голову долонями, прикрити обличчя (рот) долонею (рукавом) від збентеження (у сільській місцевості), вертіти обручку на пальці у знервованому стані. Це здебільшого вияв властивих особистості жінки надмірної емоційності, хвилювання

Фразеологізм бити по руках пов'язаний з тим, що торкання до руки іншої людини являло собою певне єднання соціуму, стало засобом сакралізації деяких домовленостей. У словнику зафіксовано таке визначення: «1) доходити згоди, домовлятися про щось (перев. при торгівлі); 2) перешкоджати чиїмсь діям (перев. злочинним), карати когось за що-небудь» і $є$ увиразником невербальних дій комунікаторів. Жест бити по руках запозичений українцями в арабів, які виражали за його допомогою скріплення торговельної угоди, хоч нині його семантичний діапазон розширився, зазнав генералізації. В українському спілкуванні цим жестом супроводжується досягнення будь-якої домовленості..

(С Г. Г. Демиденко, 2015. 
Сталий зворот переминатися (переступати) з ноги на ногу означає «тупцюючи, виявляти свою ніяковість, нерішучість, збентеження, розгубленість». Психологічний підтекст полягає в тому, що фізичний рух допомагає зняти емоційну напругу, тим самим шляхом змінити домінанту уваги, своєрідного «переключення» на ритмічні рухи, відбувається акцентуація на менш вразливій для психіки дії. Стояти на землі обома ногами означає мати тверду основу для життя, упевненість у собі, міцність переконань. Тому можна припустити, що такі якості як нерішучість, розгубленість, ніяковість виявляється в рухах ніг через невпевненість у власній позиції.

Для кваліфікації згоди використовується ПФО приставити шапку, що має стосунок до давніх звичаїв. Так, шапка символізувала загальну довіру до людини, іiі гідність, незалежність у суспільстві, окрім того, у юридичній практиці східних слов'ян ця лексема застосовувалася у процедурах свідоцтва й присяги. У давнину робити людину простоволосою означало «позбавляли іiі загального довір'я», отже, зняти з кого шапку - «зганьбити».

Стійкий вислів знімати шапку (бриль, капелюх) ховається символічний ритуал виражати свою повагу до кого-небудь, складати шану комусь. У вислові шапку ламати перед ким - спочатку догідливо кланятися, знявши головний убір, а потім принижуватися, улесливо запобігаючи в когось ласки. Ламати - тут «порушувати звичайний вигляд» шапки. Ламати (шапку), отже, «м'яти», «перебирати руками», «згинати», «давити» - як метонімічне відображення стану прохача, людини при цьому меншої, нижчої, а в разі мовленнєвої ситуації - «принизливо просити» [1].

Робота над засвоєнням паралінгвальної фразеології грунтується на розумінні семантичної специфіки фразеологізмів. Ознайомлення учнів із фразеологічним значенням вимагає застосування різних прийомів семантизації фразеологізмів: синонімізація, етимологізація, міжмовне зіставлення, описовий спосіб, спосіб наочної демонстрації (відтворення відповідної жестової одиниці), робота зі словником.

Для пізнання семантики i функціонування фразеологізмів тематичної групи «невербальна поведінка» важливе значення мають міжпредметні зв'язки української мови 3 іншими царинами знань: психологією, етнолінгвістикою, паралінгвістикою тощо.

Фразеологічні вправи, спрямовані на усвідомлення особливостей 
невербальної поведінки українців, активізують і збагачують фразеологічний запас учнів, виховують у них увагу до стійкого сполучення слів, його значення, розвивають мислення, формують мовленнєві вміння й навички, сприяють розвиткові логічного мислення старшокласників. Зміст вправ пов'язаний із пошуковою роботою, розумінням специфіки сталих зворотів у їх зв’язку 3 жестовим прототипом, осмисленням явища фразеологічної синонімії.

До подальших напрямів дослідження вважаємо за доцільне залучити вивчення психологічної і методичної основи викладання фразеології у вищій школі, зокрема зважаючи на ознайомлення 3 паралінгвальними сталими зворотами.

\section{Література}

1. Демиденко Г. Паралінгвальні фразеологізми в українській етнокультурі : [монографія] / Г. Демиденко. - Кривий Ріг : НПП АСТЕРІКС, 2014. - 175 с.

2. Кожуховська Л. П. Збагачення мовлення учнів 5-7 класів українською фразеологією : автореф. дис. ... канд. пед. наук / Л. П. Кожуховська. - К., 1999. - 19 с.

3. Лепешаў І. Я. Фразеалагічны слоўнік беларускай мовы : у 2-х т. / І. Я. Лепешаў. - Мінськ : Беларуская энцыклапедыя імя П. Броўкі, 2008. - Т. 1. -672 с. ; Т. 2 - 704 с.

4. Методика навчання української мови в середніх навчальних закладах / М. І. Пентилюк, С. О. Караман, О. В. Караман, О. М. Горошкіна, 3. П. Бакум та ін. ; за ред. М. І. Пентилюк. - К. : Ленвіт, 2004. - 400 с.

5. Мисан І. В. Психолінгвістичний та лінгводидактичний аспекти фразеології / I. В. Мисан // Вісник ЛНУ імені Тараса Шевченка. - Луганськ, 2013. - № 13 (272), Ч. III. - C. $275-282$.

6. Словник фразеологізмів української мови / [уклад. В. М. Білоноженко та ін.]. К. : Наукова думка, 2003. - 1104 с.

7. Соловець Л. О. Робота над фразеологізмами як засіб формування культури спілкування молодших школярів : автореф. дис. ... канд. пед. наук / Л. О. Соловець. K., 2004. -22 c.

8. Тесленко О. В. Міжпредметні зв'язки у процесі вивчення фразеології української мови в 5-7 класах загальноосвітньої школи : автореф. дис. ... канд. пед. наук / О. В. Тесленко. - К., 2000. - 16 с.

9. Форостюк Т. В. Активізація пізнавальної діяльності учнів 5-6 класів у процесі вивчення лексики й фразеології української мови : автореф. дис. ... канд. пед. наук / Т. В. Форостюк. - К., 2000. - 19 с.

10. Фразеологический словарь русского языка / под. ред. А. И. Молоткова. - [2-е изд., стереот.]. - М. : Советская энциклопедия, 1968. - 543 с.

11. Шумилина О.С. Стратегии идентификации иноязычных фразеологических единиц (на материале английских глагольных фразеологизмов с соматическими компонентами) : автореф. дис. ... канд. филол. наук / О. С. Шумилина. - Тверь, 1997. - 16 с.

Стаття надійшла до редакиії 16.03 .2015 p.

С Г. Г. Демиденко, 2015. 